\title{
Dysregulation of RasGRP1 in rheumatoid arthritis and modulation of RasGRP3 as a biomarker of TNFa inhibitors
}

Marie-Laure Golinski ${ }^{1,5^{*}}$, Thibault Vandhuick ${ }^{1,2}$, Céline Derambure ${ }^{1}$, Manuel Fréret ${ }^{1}$, Matthieu Lecuyer ${ }^{3}$, Clément Guillou ${ }^{1}$, Martine Hiron ${ }^{1}$, Olivier Boyer ${ }^{1,4}$, Xavier Le Loët ${ }^{1,2}$, Olivier Vittecoq ${ }^{1,2}$ and Thierry Lequerré ${ }^{1,2}$

\begin{abstract}
Background: B and T cells play a key role in rheumatoid arthritis (RA) pathophysiology. RasGRP1 and RasGRP3 are involved in T and B cell receptors signaling, and belong to gene combination able to predict infliximab responsiveness, leading to the question of RasGRP1 and RasGRP3 involvement in RA.

Methods: RasGRP1 and RasGRP3 expression levels were measured by qRT-PCR and/or western-blot in peripheral blood mononuclear cells (PBMCs), in T and B cells from untreated RA patients and in RA patients treated by TNFa inhibitors. T and $B$ cells from healthy controls $(\mathrm{HC})$ were cultured with TNFa, and TNFa receptors neutralizing antibodies to highlight the TNFa effects on RasGRP1 and RasGRP3 pathways. MAPK pathways and apoptosis were respectively analyzed using the Proteome Profiler arrays and flow cytometry.

Results: In PBMCs from RA patients, gene expression levels of RasGRP1 were invariant while RasGRP3 was downregulated under TNFa inhibitors and upregulated under TNFa. In T cells from RA patients, RasGRP1 was decreased and its gene expression level was correlated with disease activity. In T cells from HC, TNFa stimulation increased RasGRP1 gene expression level while it reduced RasGRP1 protein expression level. Bryostatin-1 experiments have confirmed that the TNFa effect observed on T cells proliferation was due to the decrease of RasGRP1 expression. Besides, RasGRP3 expression level increased in PBMCs from RA patients under TNFa and in B cells from HC leading us to conclude that RasGRP3 in B cells was modulated by TNFa.
\end{abstract}

Conclusion: This study demonstrates RasGRP1 dysregulation in RA patients while RasGRP3 is characterized as a biomarker linked to TNFa inhibitors. After binding to TNFR1, TNFa reduced RasGRP1 protein expression resulting in inhibition of $\mathrm{T}$ cell activation.

Trial registration: Clinicaltrials.gov NCT00234234, registered 04 November 2008; NCT00767325, registered 05 October 2005.

Keywords: Rheumatoid arthritis, T cells, B cells, RasGRP, TNFa inhibitors

\footnotetext{
* Correspondence: marie-laure.potier@orange.fr

'INSERM, U905 \& Normandy University, Institute for Research and Innovation

in Biomedicine (IRIB), Rouen, France

5INSERM U905, Université de Rouen, Faculté de médecine - pharmacie, 22

boulevard Gambetta, 76000 Rouen, France

Full list of author information is available at the end of the article
} 


\section{Background}

Rheumatoid arthritis (RA) is the most common inflammatory arthritis affecting $1 \%$ of the world population [1]. RA is characterized by chronic inflammation and proliferation of the synovial tissue, leading to the destruction of bone and cartilage. RA is a multifactorial disease involving genetic, environmental and hormonal factors, and immunological disorders contributing to chronic synovitis [2].

$\mathrm{B}$ and $\mathrm{T}$ lymphocytes play a central role in RA [3]. Some abnormalities of antigen receptor signaling pathways in $\mathrm{B}$ and $\mathrm{T}$ cells can lead to their dysfunction, particularly by enhancing the emergence of autoimmunity [4]. The dysfunction of various immune cells is a result of an imbalance in the production of factors which leads to the overexpression or conversely, the deletion of other factors, such as antibodies and cytokines. Among these factors, TNF $\alpha$ has been identified as a key cytokine in the pathogenesis of RA maintaining joint inflammation $[5,6]$. Indeed, the use of anti-TNF $\alpha$ drugs has allowed eliciting remission in a high proportion of RA patients even if $30 \%$ of patients do not respond to them [7]. Studies have been performed to highlight predictive biomarkers of response to TNF $\alpha$ inhibitors, including RasGRP3 [8]. RasGRP3 has also been found to be dysregulated in peripheral blood mononuclear cells (PBMCs) and synovium from RA patients [8, 9]. Furthermore, RasGRP1 has been associated with susceptibility to RA [10].

RasGRP is a member of the CDC25 family of ras guanyl nucleotide exchange factors that contain an $\mathrm{N}$-terminal GEF domain and C-terminal calcium-binding and diacylglycerol (DAG)-binding domains [11]. In mouse, RasGRP3 is expressed in B cells whereas RasGRP1 is highly expressed in $\mathrm{T}$ cells and to a lesser extent in B cells [12-16]. These proteins are involved in $\mathrm{T}$ and $\mathrm{B}$ cell receptor (respectively TCR and BCR) signaling $[17,18]$. RasGRP1 also plays a role in NF- $\mathrm{kB}$ pathway inhibition in B cells, leading to their apoptosis [19]. Ras activation by RasGRP proteins stimulates various effectors systems, leading to changes in gene expression that are critical for $\mathrm{T}$ or $\mathrm{B}$ cell development [20-22]. Indeed, RasGRP1 $1^{-1-}$ mice become autoimmuneprone and develop a lupus-like phenotype [20, 22, 23]. These mice displayed an increase of autoreactive $\mathrm{CD}^{+} \mathrm{T}$ cells, which is the consequence of a lack of positive selection in the thymus, thus facilitating the activation of B cells and the production of auto-antibodies $(\mathrm{Ab})[12,13]$. In contrast, RasGRP3 ${ }^{-/-}$mice exhibit hypogammaglobulinemia and show no sign of autoimmunity [12, 20]. Remarkably, double mutant mice do not develop signs of autoimmunity [12]. Therefore, RasGRP1 inhibition promotes autoimmunity via activation of $\mathrm{B}$ cells by autoreactive $\mathrm{CD} 4^{+} \mathrm{T}$ cells, while RasGRP3 inhibition renders $B$ cells less sensitive to $\mathrm{T}$ cell signals [20].

The identification of RasGRP3 as a biomarker of antiTNF $\alpha$ drugs raises the question as to whether RasGRP is a biomarker related to RA pathology or to the treatment. We therefore investigated RasGRP1 and RasGRP3 gene expression in patients treated by two TNF $\alpha$ inhibitors, adalimumab and etanercept, and in untreated RA patients compared to healthy controls (HC).

\section{Methods \\ Subjects}

A total of 60 patients (adalimumab $(n=21)$, etanercept $(\mathrm{n}=9)$ or abatacept $(\mathrm{n}=30))$ were included to measure the impact of biologic agents on RasGRP1 and RasGRP3 expression levels (Additional file 1: Table S1). Patients treated with adalimumab or etanercept fulfilling the 1987 American College of Rheumatology (ACR) or the 2010 ACR/European League Against Rheumatism (EULAR) criteria for RA were included in the multicenter SATRAPE study (NCT00234234), approved by the ethics committee of Upper-Normandy in France $\left(n^{\circ} 2005 / 006\right)$ [24, 25]. RA patients treated with abatacept, who were used as controls came from the APPRAISE study (NCT00767325) approved by the ethics committee of CPP (Comité de Protection des Personnes) in France [26]. RA patients were treated as recommended by the manufacturer and the French Drug Agency ANSM (50 mg every week for etanercept, $40 \mathrm{mg}$ each other week for adalimumab patients by subcutaneous injections and $10 \mathrm{mg} / \mathrm{kg}$ every month by intravenous injections for abatacept). Clinical and biological characteristics such as age, gender, tender and/or swollen joint count, disease activity score (DAS28), treatments and their dose, health assessment questionnaire, serum $\mathrm{C}$-reactive protein level and erythrocyte sedimentation rate, were recorded just before the first injection and 3 months later.

To compare RasGRP1 and RasGRP3 expression levels in $\mathrm{RA}$ patients and $\mathrm{HC}, 20 \mathrm{HC}$ (6 male and $14 \mathrm{fe}-$ male; $32 \pm 9$ years old) and 32 untreated RA patients (9 male and 23 female; $53 \pm 15$ years old) were studied (Additional file 2: Table S2). At the time when RasGRP1 and RasGRP3 expression levels were measured, DAS28 was $4.98 \pm 1.32$. The PBMCs from RA patients or $\mathrm{HC}$ were collected from whole venous blood. All participants signed an informed consent at the time of enrollment.

PBMCs were isolated from the buffy-coat of $\mathrm{HC}$ to perform in vitro studies.

\section{Purification of $\mathrm{T}$ and $\mathrm{B}$ cells}

PBMCs were extracted from whole venous blood or buffy coat using Ficoll-Hypaque (Lymphoprep ${ }^{\mathrm{Tn}}$, Oslo, Norway). T and B cells were purified by negative selection using human $\mathrm{T}$ and $\mathrm{B}$ cell Dynabeads, respectively, according to the manufacturer's instructions (Invitrogen $^{\mathrm{T}}$, Carlsbad, CA, USA). 


\section{Lymphocyte cultures}

One million PBMCs, $\mathrm{T}$ or $\mathrm{B}$ cells/well were cultured into 24-well plates with $1 \mathrm{ml}$ of RPMI 1640 medium supplemented with $10 \%$ fetal calf serum (FCS), and $0.5 \%$ penicillin and streptomycin. PBMCs or lymphocytes were cultured with or without $1 \mathrm{ng} / \mathrm{ml}$ of TNFa (R\&D Systems, Minneapolis, MN, USA) and with or without adalimumab $(1 \mu \mathrm{g} / \mathrm{ml})$, etanercept $(10 \mu \mathrm{g} / \mathrm{ml})$, infliximab $(100 \mu \mathrm{g} / \mathrm{ml})$, certolizumab $(1 \mu \mathrm{g} / \mathrm{ml})$ or golimumab $(100 \mu \mathrm{g} / \mathrm{ml})$ for 24 or 48 hours in a $5 \% \mathrm{CO}_{2}$ incubator at $37{ }^{\circ} \mathrm{C}$. In neutralizing experiments, $\mathrm{B}$ and $\mathrm{T}$ cells were preincubated with anti-TNF receptor (TNFR)1 $(9 \mu \mathrm{g} / \mathrm{ml})$ or anti-TNFR2 $(2.5 \mu \mathrm{g} / \mathrm{ml})$ (R\&D Systems) for 1 hour and TNF $\alpha$ was added for 48 hours. In activation experiments, $\mathrm{T}$ cells were incubated with IL-2 $(60 \mathrm{U} / \mathrm{ml})$ and anti-CD3 antibody $(5 \mu \mathrm{g} / \mathrm{ml})$ for 4 days. For experiments with Bryostatin-1, cells were incubated with TNF $\alpha$ for 48 hours. Cells were then activated with $50 \mathrm{nM}$ Bryostatin-1 (Sigma-Aldrich, Saint Louis, MO, USA) for 5 hours. Cells were then harvested for flow cytometry analysis or RNA and protein extraction.

\section{Flow cytometry analysis}

To control the purity of cell selection, the following antibodies (BD Pharmingen ${ }^{\text {tw }}$, Franklin Lakes, NJ, USA) were used: anti-CD3, anti-CD4, anti-CD8, anti-CD14, antiCD19 and anti-CD56. Antibodies used for TNF receptor expression (anti-TNFR1 and anti-TNFR2) were purchased from R\&D Systems (R\&D Systems). To bring out the $T$ cell activation, the following antibodies (Beckman Coulter, Brea, CA, USA) were used: anti-CD3, anti-CD25, antiHLA-DR. To bring out the early $\mathrm{T}$ cell activation, the marker CD69 was studied after TNF $\alpha$ stimulation by flow cytometry (BD Pharmingen ${ }^{\mathrm{Tx}}$ ). To detect apoptosis in $\mathrm{T}$ cells after TNF $\alpha$ stimulation, a fluorescein isothiocyanate (FITC) annexin-V Apoptosis Detection Kit (Becton-Dickinson, Franklin Lakes, NJ, USA) was used. Appropriate isotype controls were used in all cases. Acquisition of samples was performed on a FACSCanto flow cytometer (Becton-Dickinson), and the data were analyzed with FlowJo software.

\section{Quantitative measurement of RasGRP1 and RasGRP3 mRNA abundance}

RNA samples were obtained using the RNAqueous 4-PCR kit according to the manufacturer's instructions (Ambion ${ }^{\odot}$, Austin, TX, USA). cDNA was then synthesized using random primers and M-MLV enzyme (Invitrogen ${ }^{\mathrm{TM}}$ ). Quantitative (q)RT-PCR was performed using a Lightcycler as instructed by the manufacturer (Roche ${ }^{\mathrm{Tx}}$, Meylan, France). We chose primers that recognize normal and abnormal RasGRP1 mRNA. Sequences of primers used for qRT-PCR were : RasGRP1 forward, 5'-TGCACCGAATTGTCATCT CC-3'; RasGRP1 reverse, 5'-GTCAATCAGGCGGCAAT
GTA-3'; RasGRP3 forward, 5'-CACGGTCATCAACAAG CACA-3'; RasGRP3 reverse, 5'-CAGTGTTCGCAGAAG GTTGG-3'; $18 S$ forward, 5'-GTGGAGCGATTTGTCTG GTT-3'; $18 S$ reverse, 5'-CGCTGAGCCAGTCAGTGTA G-3' (Eurogentec ${ }^{\mathrm{Tm}}$, Fremont, CA, USA). qRT-PCR reactions for each sample were performed in triplicate using SYBR-Green and values corrected using control $18 \mathrm{~S}$ to calibrate $\left(\right.$ Roche $\left.^{\mathrm{TM}}\right)$.

\section{Lymphocyte proliferation assay}

Cell proliferation is evaluated by incorporation of $\left({ }^{3} \mathrm{H}\right)$ thymidine. Fifty thousand cells/well of $\mathrm{B}$ or $\mathrm{T}$ cells in $200 \mu \mathrm{l}$ of RPMI containing 10 \% FCS were seeded into 96well plates. Lymphocytes were cultured with or without TNFa (for 48 and 72 hours) in a $5 \% \mathrm{CO}_{2}$ incubator at $37{ }^{\circ} \mathrm{C}$. After these incubations, $1 \mu \mathrm{Ci}$ of $\left({ }^{3} \mathrm{H}\right)$-thymidine was added to each well. $\left({ }^{3} \mathrm{H}\right)$-thymidine incorporation was quantified 16 hours later.

\section{Signaling pathway analysis}

A human phospho-kinase Proteome Profiler ${ }^{\mathrm{Tm}}$ array $(\mathrm{R} \& \mathrm{D}$ Systems) was used to investigate the mitogen-activated protein kinase (MAPK) signaling pathways. To conduct this experiment, B and T cells were rinsed twice with PBS, and lysis buffer was added. Cell lysates were gently rocked for 30 minutes at $4{ }^{\circ} \mathrm{C}$ and then centrifuged at $14,000 \mathrm{~g}$ for 5 minutes $\left(4^{\circ} \mathrm{C}\right)$. A total of $200 \mu \mathrm{g}$ of protein was used for each array. Human phospho-kinase was purchased from R\&D Systems. Proteins were visualized using a chemiluminescence detection system. Arrays were exposed to x-ray films (5-45 minutes) and developed under standard conditions. The intensity of the immunoreactive bands was quantified using a blot analysis system (BioRad Laboratories, Hercules, CA, USA).

\section{Immunoblot analysis}

$\mathrm{B}$ and $\mathrm{T}$ cells were incubated with RIPA supplemented with a protease inhibitor for 30 minutes. Homogenates were then centrifuged at $16,000 \mathrm{~g}$ for 10 minutes at $4{ }^{\circ} \mathrm{C}$. The protein concentration of supernatant was quantified using the bicinchoninic acid kit (Pierce Biotechnology, Rockford, IL, USA). Lysates were suspended in Laemmli buffer (100 mM Hepes, pH 6.8, 10 \% $\beta$-mercaptoethanol, $20 \%$ SDS) and boiled for 10 minutes. Proteins (15 to $40 \mu \mathrm{g}$ ) were loaded and resolved on $12 \%$ SDS-PAGE gels. After electrophoretic separation at $200 \mathrm{~V}$ for 1 hour, proteins were transferred to a polyvinylidene difluoride membrane at $30 \mathrm{~V}$ for 2 hours. Membranes were then incubated in a blocking solution (5\% BSA in Tris-buffered saline containing $0.1 \%$ Tween 20) at room temperature for 1 hour and incubated overnight with one of the following primary antibodies: mouse anti-human-RasGRP1 (Merck Millipore, Molsheim, France), mouse anti-human-RasGRP3 (Abcam, Cambridge, MA, USA), mouse anti-human-extracellular 
signal-regulated kinase (ERK)1/2 (Merck Millipore), mouse anti-human-phospho-ERK1/2 (Cell Signaling Technology, Danvers, MA, USA) or mouse anti-human-glyceraldehyde3-phosphate dehydrogenase (GAPDH) (Sigma-Aldrich). After incubation with the corresponding secondary antibodies coupled to peroxidase (Santa-Cruz Biotechnology, Santa-Cruz, CA, USA), proteins were visualized using enhanced chemiluminescence ECL immunoblotting detection system (Amersham, UK). Arrays were exposed to x-ray films (5-20 minutes) and developed under standard conditions. The intensity of the immunoreactive bands was quantified using a blot analysis system (BioRad Laboratories). Results are reported relative to GAPDH.

\section{Statistical analysis}

One-way analysis of variance (ANOVA) followed by Dunnett post-hoc test was used to compare RasGRP1 and RasGRP3 gene expression levels between different groups of patients and $\mathrm{HC}$ and for the proliferation assay. One-way ANOVA followed by Bonferroni posthoc test was used to compare RasGRP1 and RasGRP3 gene expression levels with or without TNF $\alpha$ and TNF $\alpha$ inhibitors in HC, and RasGRP1 and RasGRP3 expression levels with or without TNF $\alpha$ and anti-TNFR treatment. The nonparametric Wilcoxon paired test was used to compare baseline and post-treatment RasGRP1 and RasGRP3 gene expression levels. Comparison of two populations was made with Student's $t$ test. Correlations were assessed using Pearson's rank correlation coefficient.

\section{Results}

RasGRP3 gene expression level decreased in PBMCs from RA patients treated by TNFa inhibitors

To better understand the effects of TNFa inhibitors on RasGRP3, gene expression levels in PBMCs from RA patients were compared before and after 3 months (V2) of treatment with an antibody targeting TNFo (adalimumab) or a soluble receptor of TNF $\alpha$ (etanercept), or after 6 months of treatment with abatacept (CTLA4-Ig fusion protein), another family of biologic agent used in RA as a control. RasGRP3 gene expression level was significantly decreased under adalimumab $(p<0.001)$ or etanercept $(p<0.05)$ after 3 months of treatment (Fig. 1a). RasGRP is also involved in immune processes, but the RasGRP1 gene expression level was not significantly dysregulated under TNF $\alpha$ inhibitors
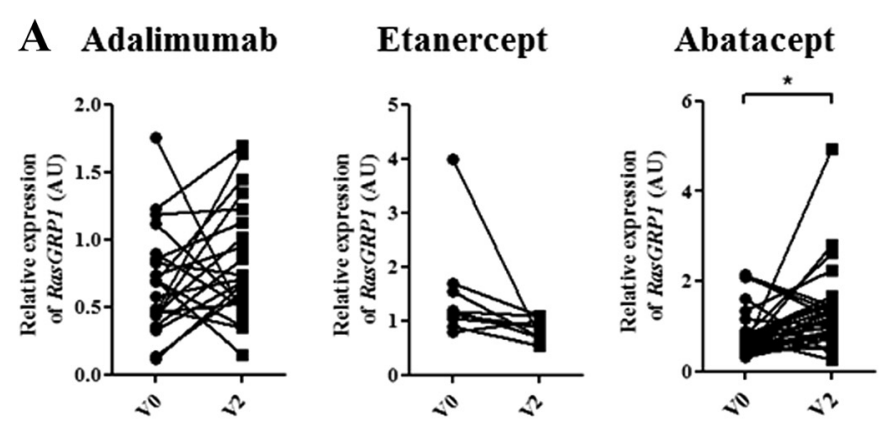

B
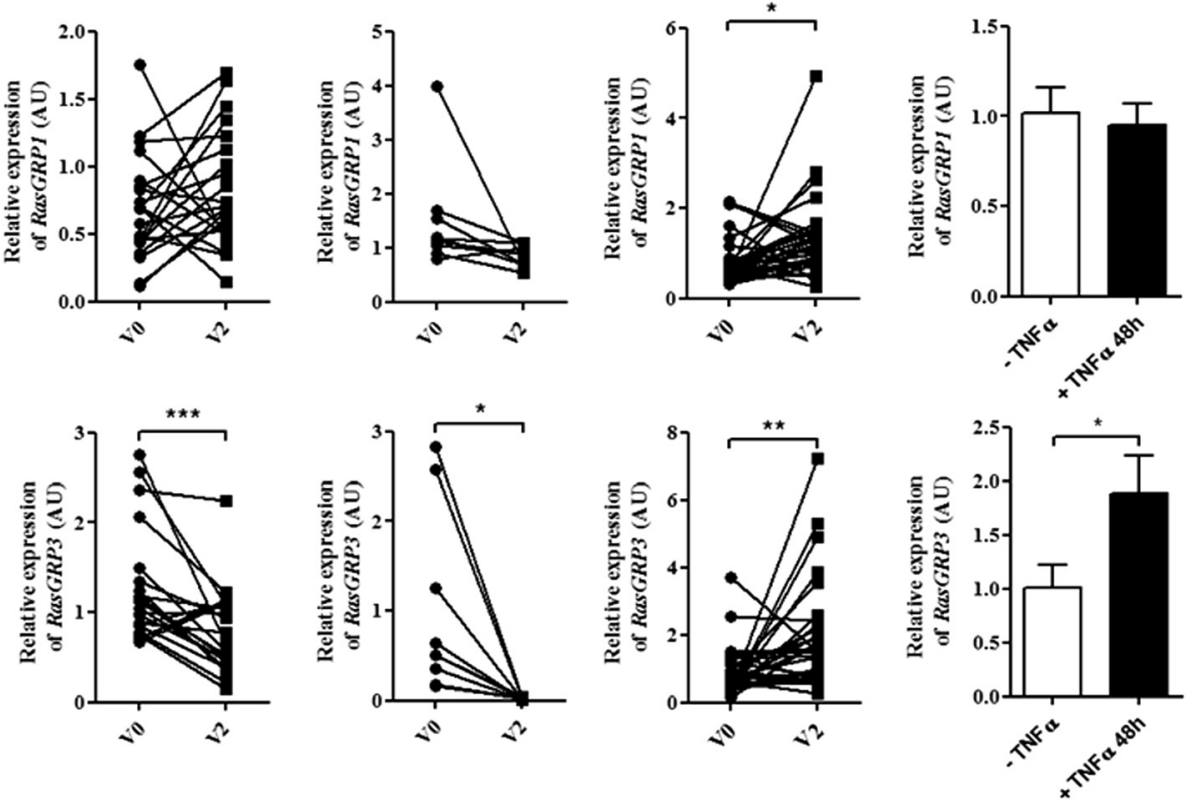

Fig. 1 RasGRP1 and RasGRP3 gene expression fluctuations in periperhal blood mononuclear cells (PBMCs) from patients with rheumatoid arthritis (RA) treated with biologic agents at baseline and after treatment or after in vitro TNFa stimulation. a PBMCs were isolated from whole blood from RA patients treated with adalimumab ( $n=21 ; 4$ male and 17 female; $52 \pm 3$ years old) and etanercept $(n=9 ; 4$ male and 5 female; $54 \pm$ 5 years old) before treatment (V0) and 3 months later (V2) or abatacept ( $n=30 ; 3$ male and 27 female; $61 \pm 1$ years old) before treatment (V0) and 6 months later (V2). b PBMCs were isolated from whole blood of RA patients untreated with biologics $(n=6 ; 1$ male and 5 female; $54 \pm 10$ years old) and cultured with or without TNFa for 24, 48 or 72 hours. Quantitative PCR analysis was performed to measure RasGRP1 and RasGRP3 gene expression levels. The relative expression levels (in arbitrary units (AU)) of RasGRP1 and RasGRP3 were normalized with 185 RNA abundance. Mean \pm standard error of the mean were compared using Student's $t$ test or the Wilcoxon paired test: ${ }^{*} p<0.05 ;{ }^{* *} p<0.01 ;{ }^{* * *} p<0.001$ 
(Fig. 1a). Otherwise, RasGRP1 $(p<0.05)$ and RasGRP3 $(p<0.01)$ gene expression levels were significantly increased in patients after 6 months of treatment with abatacept (Fig. 1a).

To highlight the effects of all TNF $\alpha$ inhibitors available on RasGRP3 gene expression levels in in vitro conditions, PBMCs from $\mathrm{HC}$ were incubated with or without TNFo and TNFa inhibitors for 1.5, 6.0, 24.0 and 48.0 hours. TNF $\alpha$ induced a significant increase of RasGRP3 gene expression levels only after 48.0 hours of stimulation (Additional file 3) while any modulation was observed at early time: 1.5, 6.0 and 24.0 hours (data not shown). This increase of RasGRP3 gene expression level was inhibited by all TNFo inhibitors (Additional file 3). As expected, no effect on RasGRP3 gene expression level in PBMCs was observed when TNF $\alpha$ inhibitors were added to the cultures without TNFa (data not shown). All together, these results indicate that the decrease of RasGRP3 gene expression level is specifically associated with all TNF $\alpha$ inhibitors, raising the question about the effects of TNF $\alpha$ on RasGRP3 expression in RA patients.

\section{RasGRP3 gene expression level increased in PBMCs from RA patients stimulated by TNFa}

To investigate the involvement of TNF $\alpha$ in RasGRP1 and RasGRP3 gene expression levels in PBMCs from RA patients, these cells were incubated with or without TNF $\alpha$ for 48 hours. TNFo induced a significant increase of RasGRP3 gene expression level $(p<0.05)$ (Fig. 1b) as observed in PBMCs from HC (Additional file 3), without an effect on RasGRP1 gene expression level (Fig. 1b).

\section{RasGRP1 and RasGRP3 were respectively expressed in T and $B$ cells from $\mathrm{HC}$}

While a few studies have described RasGRP1 and RasGRP3 expression on $\mathrm{T}$ and $\mathrm{B}$ cells in mice or in cell lines $[12,21]$, several studies have only described the expression of RasGRP1 in T cells [27-30], raising the question of RasGRP3 expression in human. After negative selection, the B and T cell purity was $91 \%( \pm 0.1 \%)$ and $96 \%( \pm 0.02 \%)$, respectively (Additional file 4$)$. In $\mathrm{HC}$, RasGRP1 gene expression level was significantly higher in T cells than in B cells $(p<0.01)$. Conversely, RasGRP3 gene expression level was significantly higher in B cells than in T cells $(p<0.001)$ (Fig. 2a). RasGRP1 and RasGRP3 were unexpressed respectively in $\mathrm{B}$ and $\mathrm{T}$ cells.

\section{RasGRP1 was dysregulated in T cells from RA patients}

RasGRP1 and RasGRP3 gene expression levels were next measured in $\mathrm{T}$ and $\mathrm{B}$ cells from RA patients compared to HC. RasGRP1 gene expression level was significantly overexpressed in T cells from RA $(p<0.01)$ (Fig. 2b) while RasGRP3 gene expression level in B cells was not significantly different between RA patients and $\mathrm{HC}$ (Fig. 2c). To link RasGRP1 or RasGRP3 with RA, we assessed the correlation between DAS28 and gene expressions. RasGRP1 gene expression level in T cells was inversely correlated with the RA disease activity measured by DAS28 in 24 RA patients $(p<0.05)$ (Fig. 2d). No correlation between RasGRP3 gene expression level and DAS28 in B cells was found (data not shown).

To determine whether the increasing of RasGRP1 mRNA expression level was due to a modification of RasGRP1 function/signaling or if it reflected the activation status of the $\mathrm{T}$ cells, $\mathrm{T}$ cells were activated for 4 days with IL-2 and anti-CD3 antibody. First, we confirmed that $\mathrm{T}$ cells activation markers HLA-DR and CD25 were overexpressed after 4 days of stimulation by flow cytometry (Additional file 5A). Second, RasGRP1 gene expression level was significantly increased $(p<0.001)$ after $\mathrm{T}$ cell activation (Additional file 5B).

To confirm these results at the protein level, RasGRP1 and RasGRP3 expression level were measured by western blot respectively in $\mathrm{T}$ and $\mathrm{B}$ cells from RA patients compared to HC. Unexpectedly, the expression of RasGRP1 in T cells from RA patients was $50 \%$ lower $(p=0.05)$ while RasGRP3 protein expression level in B cells was not significantly different (Fig. 3). Altogether these results indicate that RasGRP1 is associated with RA disease activity, whereas RasGRP3 was not involved in RA pathophysiology. Surprisingly, the gene and protein RasGRP1 expression changed in the opposite sense in RA patients.

\section{TNFa influences RasGRP1 and RasGRP3 gene expression levels respectively in $T$ and $B$ cells}

In RA, TNFa is a key pro-inflammatory cytokine involved in RA pathophysiology and is also a therapeutic target. To better understand the involvement of TNF $\alpha$ on RasGRP1 and RasGRP3 gene expression levels on $\mathrm{T}$ and $\mathrm{B}$ cells, respectively, these cells from buffy coats were incubated with or without TNF $\alpha$ for 24 or 48 hours. TNF $\alpha$ induced an increase of RasGRP1 ( $p$ $<0.001)$ and RasGRP3 $(p<0.01)$ gene expression levels after 48 hours of stimulation (Fig. 4a). To further investigate the potential role of TNFR1 and/or TNFR2 in TNF $\alpha$ induced increase of RasGRP1 or RasGRP3 gene expression levels, we studied the effects of two antibodies neutralizing TNFR1 and TNFR2 specifically. First, we confirmed that TNFR1 and TNFR2 were expressed in B and $\mathrm{T}$ cells by flow cytometry (Fig. 4b). Second, the TNFR1 and TNFR2 neutralizing antibodies inhibited the TNF $\alpha$-induced increase of RasGRP1 $(p<0.001)$ and RasGRP3 $(p<0.05)$ gene expression levels in T and B cells respectively (Fig. 4c). No effect was observed when $\mathrm{T}$ or B cells were treated only with TNFR1 or TNFR2 

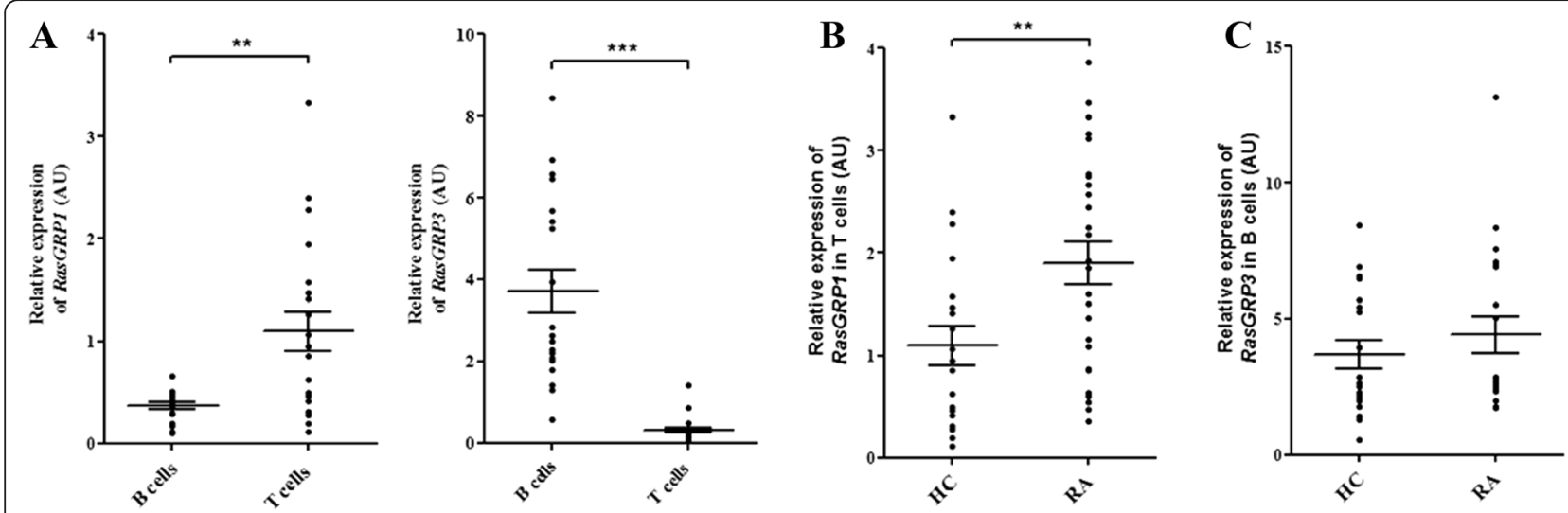

D

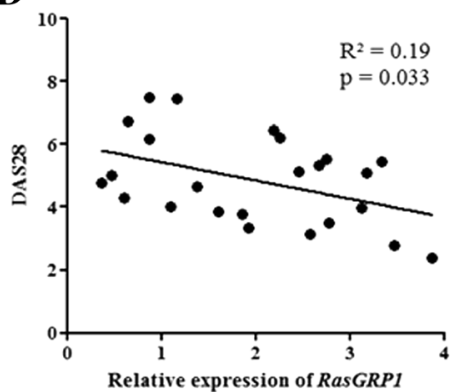

in $\mathrm{T}$ cells $(\mathrm{AU})$

Fig. 2 RasGRP1 and RasGRP3 gene expression levels in B and T cells from healthy controls and patients with rheumatoid arthritis (RA). After T and B cell negative selection, quantitative PCR analysis of RasGRP1 and RasGRP3 gene expression was performed. a RasGRP1 and RasGRP3 gene expression levels in $B$ and T cells from healthy controls (HC) $(n=20 ; 6$ male and 14 female; $32 \pm 9$ years old). $\mathbf{b}$ RasGRP1 and $\mathbf{c}$ RasGRP3 gene expression levels respectively in T and B cells from HC ( $n=20 ; 6$ male and 14 female; $32 \pm 9$ years old) and patients with RA ( $n=26 ; 8$ male and 18 female; $53 \pm 15$ years old). d Correlation between RasGRP1 gene expression level in T cells and RA disease activity (disease activity score in 28 joints (DAS28)) was assessed using Pearson's rank correlation coefficient. The relative expression levels (in arbitrary units (AU)) of RasGRP1 and RasGRP3 were normalized with 18 S RNA abundance. Mean \pm standard error of the mean were compared using the Wilcoxon paired test or oneway analysis of variance followed by Dunnett post-hoc test. ${ }^{*} p<0.05 ;{ }^{* *} p<0.01$; ${ }^{* * *} p<0.001$

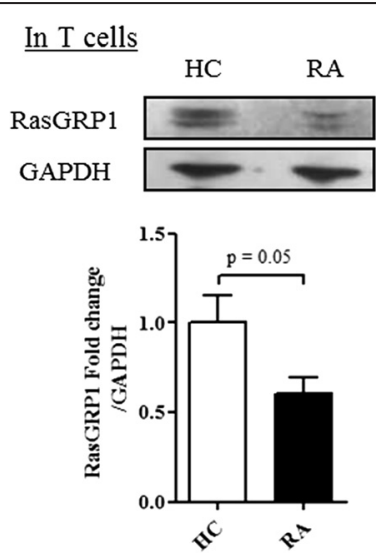

\begin{tabular}{llll} 
& \multicolumn{1}{c}{ In B cells } & & \\
& & HC $\quad$ RA & \\
$90 \mathrm{kDa}$ & RasGRP3 & & \\
$37 \mathrm{kDa}$ & GAPDH & & \\
\cline { 3 - 3 } & & &
\end{tabular}

Fig. 3 RasGRP1 and RasGRP3 protein expression levels in T and B cells in healthy controls (HC) and rheumatoid arthritis (RA) patients. Western blot analysis was performed to measure RasGRP1 and RasGRP3 protein expression in T and B cells, respectively. RasGRP1 protein expression was measured in T cells from HC $(n=4)$ and RA patients $(n=5)$. RasGRP3 protein expression was measured in B cells from HC $(n=4)$ and RA patients $(n=3)$. A value of 1 was arbitrarily assigned to control conditions to which glyceraldehyde-3-phosphate dehydrogenase (GAPDH) was reported and expressed as fold change. Mean \pm standard error of the mean were compared using Student's $t$ test 

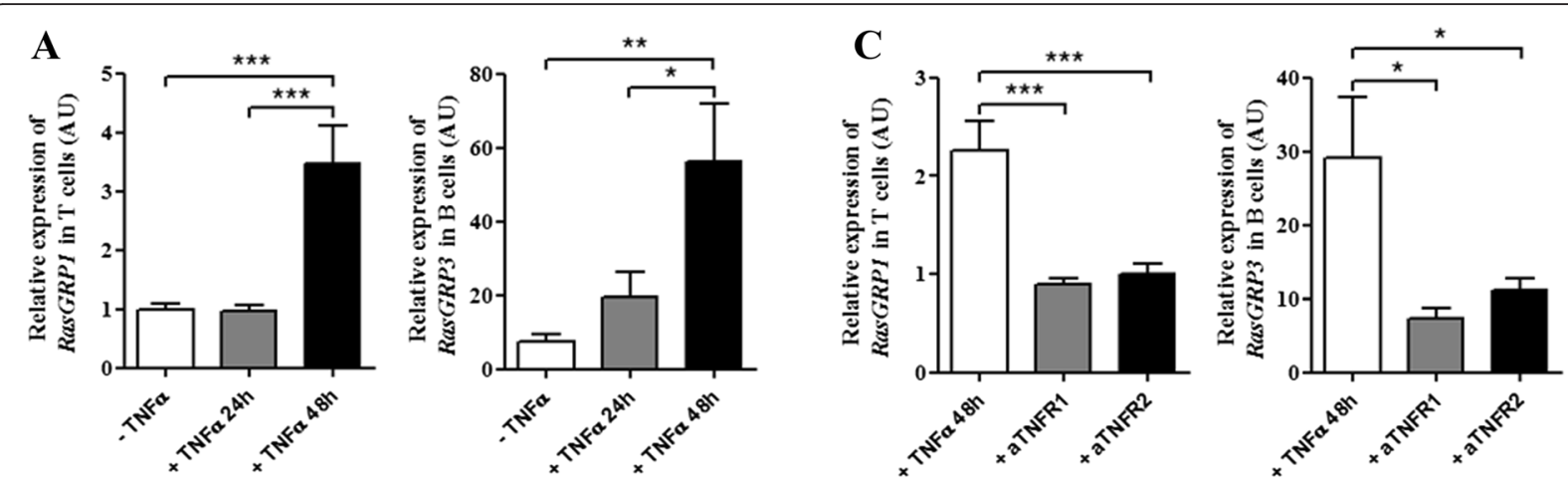

B
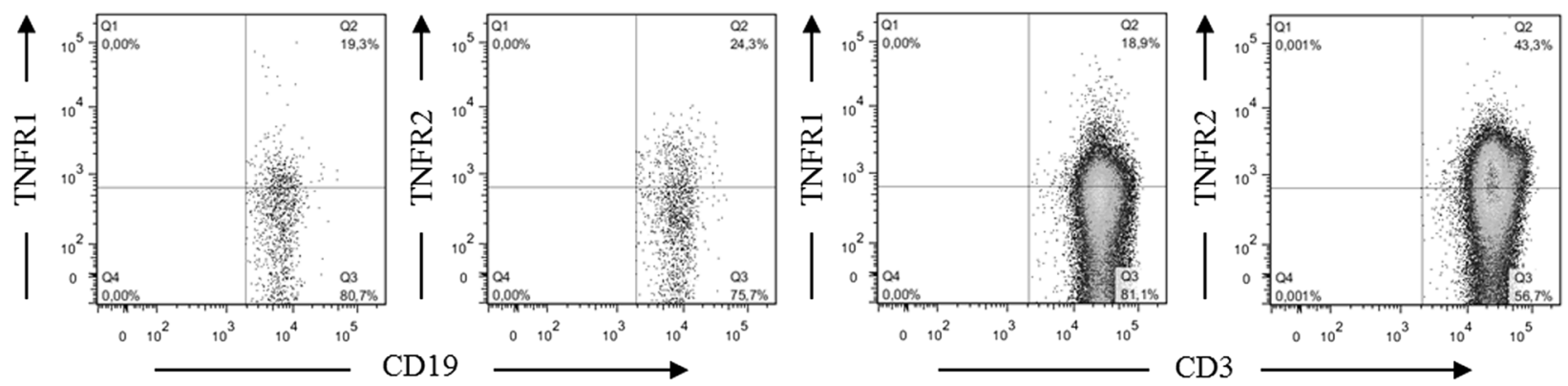

Fig. 4 TNFa influences RasGRP1 and RasGRP3 gene expression levels in T and B cells respectively via TNFR1 and TNFR2. a Quantitative PCR analysis was performed to measure RasGRP1 and RasGRP3 gene expression levels in T and B cells, respectively, obtained from three buffy coats. In each condition, cells were cultured with or without TNFa for 24 and 48 hours. b TNF receptor (TNFR)1 and TNFR2 expression in B (CD19) and T cells (CD3) was checked by flow cytometry. c Quantitative PCR analysis was performed to measure RasGRP1 and RasGRP3 gene expression levels in T and B cells, respectively, from three buffy coats. In each condition, T or B cells, previously exposed to anti-TNFR1 or anti-TNFR2 neutralizing antibodies, were cultured with TNFa for 48 hours. The relative expression levels (in arbitrary units (AU)) of RasGRP1 and RasGRP3 were normalized with 185 RNA abundance. Mean \pm standard error of the mean were compared using one-way analysis of variance followed by Bonferroni post-hoc test: ${ }^{*} p<0.05$; ${ }^{* *} p<0.01$; ${ }^{* *} p<0.001$

neutralizing antibodies (Additional file 6). No synergistic effect on RasGRP1 and RasGRP3 gene expression levels was observed when both TNFR1 and TNFR2 antibodies were simultaneously added to the cultures (data not shown). These experiments showed that TNF $\alpha$ modifies RasGRP1 or RasGRP3 expression via TNFR1 or TNFR2.

\section{TNFa influences RasGRP1 and RasGRP3 protein expression levels respectively in $T$ and $B$ cells}

In $\mathrm{T}$ cells, TNF $\alpha$ induced a significant decrease of RasGRP1 protein expression level after 48 hours of stimulation $(p<0.05)$. As previously demonstrated in $\mathrm{T}$ cells from RA patients, the RasGRP1 gene (Fig. 4a) and protein (Fig. 5a) expressions changed in the opposite sense under TNF $\alpha$ stimulation. The use of TNFR1 neutralizing antibodies with TNFa had no effect on RasGRP1 expression while TNFR2 neutralizing antibodies with TNF $\alpha$ decrease RasGRP1 expression suggesting the participation of TNFR1 for RasGRP1 expression (Fig. 5a). In B cells, TNF $\alpha$ induced an increase of RasGRP3 protein expression level after 48 hours of stimulation $(p<0.05)$ (Fig. $5 \mathrm{~b})$ but TNF $\alpha$ had no effect on RasGRP3 protein expression level after previous neutralization of TNFR1 or TNFR2 (Fig. 5b). Overall, TNF $\alpha$ increased the RasGRP1 gene expression level while it decreased RasGRP1 protein expression independently of TNFR2. On the contrary, TNF $\alpha$ increased RasGRP3 mRNA and protein expression levels via TNFR1 or TNFR2.

\section{Functional effects of TNFa on T and B cells}

RasGRP1 and RasGRP3 are involved respectively in TCR and BCR signaling pathways. TNF $\alpha$ modulates RasGRP1 and RasGRP3 in T and B cells, respectively. To date, no link between TNFR1 or TNFR2 and RasGRP1 or RasGRP3 has been described in the literature. Therefore, we characterized the TNF $\alpha$ effects in upstream and downstream of RasGRP1 and RasGRP3 on TCR and BCR signaling pathways. First, we evaluated cell proliferation under TNF $\alpha$ by $\left({ }^{3} \mathrm{H}\right)$ thymidine incorporation. After 72 hours of stimulation, TNF $\alpha$ reduced proliferation only on T cells $(p<0.05)$ (Fig. 6a) without apoptosis increasing (Additional file 7).

To better understand the decrease of $\mathrm{T}$ cell proliferation induced by TNF $\alpha$ and the putative link between RasGRP1 and TNFR1, a human phospho-kinase array kit was used to measure Lyn, Lck, phospholipase- $\mathrm{C} \gamma 1$ (PLCY1) (upstream of RasGRP), MEK, ERK and RSK 

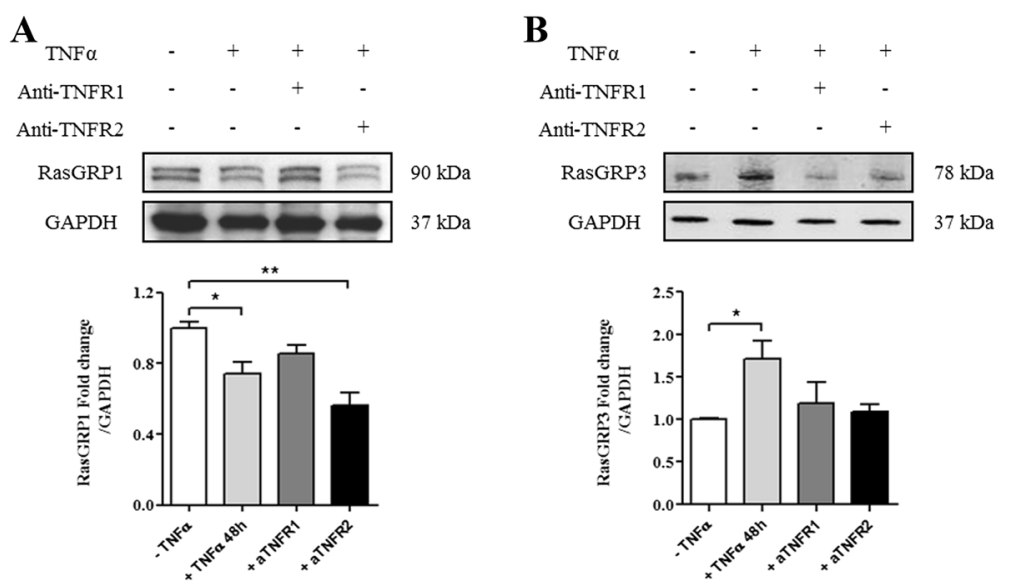

Fig. 5 TNFa influences RasGRP1 and RasGRP3 protein expression levels respectively in T and B cells via TNF receptor (TNFR) 1 and TNFR2. Western blot analysis was performed to measure RasGRP1 protein expression in T cells from five healthy controls (HC) (a) and RasGRP3 protein expression in B cells from three HC (b). In the control condition, cells were cultured without TNFa treatment. Cells were cultured with TNFa for 48 hours and with or without antibodies targeting TNFR1 or TNFR2. A value of 1 was arbitrarily assigned to control conditions (without TNFa treatment) to which glyceraldehyde-3-phosphate dehydrogenase (GAPDH) was reported and expressed as fold change. Mean \pm standard error of the mean were compared using one-way analysis of variance followed by the Dunnett post-hoc test: ${ }^{*} p<0.05 ;{ }^{* *} p<0.01$

(downstream of RasGRP) phosphorylation after 48 hours of TNFa stimulation. Indeed, the antigen binding to TCR or BCR, co-localized respectively with Lck and Lyn, induced RasGRP activation via the PLC $\gamma 1$ [17, 18, 22]. The RasGRP proteins activate the small GTPase Ras resulting in the activation of the MAPK cascade Ras-Raf-MEKERK-RSK $[18,31]$. TNF $\alpha$ induced significant inhibition of Lck, ERK and RSK phosphorylation $(p<0.05)$ in T cells while TNF $\alpha$ had no significant effect on protein pathway phosphorylations in B cells (Fig. 6b). To confirm that TNF $\alpha$ inhibits ERK phosphorylation, $\mathrm{T}$ cells were incubated with or without TNF $\alpha$ and TNFR1 and TNFR2 neutralizing antibodies. TNF $\alpha$ induced a significant decrease of ERK phosphorylation after 48 hours of stimulation $(p<0.05)$ (Fig. $6 \mathrm{c})$. Whereas the use of TNFR1 neutralizing antibodies seems to inhibit the TNF $\alpha$-induced decrease of ERK phosphorylation, the use of TNFR2 neutralizing antibodies had no effect on TNF $\alpha$ action (Fig. 6c). These results confirm the results obtained with RasGRP1 shown in Fig. 5a. So, TNF $\alpha$ induced a significant decrease of RasGRP1 protein expression level after 48 hours of stimulation, followed by an inhibition of ERK phosphorylation and T cell proliferation (Fig. 6). To confirm that inhibition of ERK phosphorylation and $\mathrm{T}$ cell proliferation is due to the decrease of RasGRP1 expression, $\mathrm{T}$ cells were stimulated with Bryostatin-1 (an activator of RasGRP1) for 5 hours after TNF $\alpha$ incubation. CD69 expression (a marker of T cell activation) was measured by flow cytometry. Bryostatin-1 induced CD69 expression in human T cells (Fig. 6d, left and middle panels). However, TNF $\alpha$ inhibited the increase of CD69 expression induced by Bryostatin-1 (74 \% versus 58 \%) (Fig. 6d, right panel). In conclusion, TNF $\alpha$ binding to TNFR1 inhibits RasGRP1 expression, followed by inhibition of ERK phosphorylation and subsequent decrease in $\mathrm{T}$ cell proliferation.

\section{Discussion}

Previous studies conducted in our laboratory have identified RasGRP3 as a biomarker of TNF $\alpha$ inhibitor (infliximab) response and RA synovial tissue [8, 9]. These observations and the literature analysis lead us to wonder whether RasGRP family proteins have a role in RA. As RasGRP2 and RasGRP4 are expressed respectively in neuronal cells and mast cells [13, 21], we focused our study on RasGRP1 and RasGRP3 expression involved respectively in TCR and BCR signaling.

We demonstrated the preferential expression of RasGRP1 and RasGRP3 mRNAs, respectively, in human $\mathrm{T}$ and $\mathrm{B}$ cells. The other data available on RasGRP1 and RasGRP3 are derived from experimental studies in mice, from cell lines and from systemic lupus erythematosus (SLE) T cells $[12,20]$. These experiments showed that in mice RasGRP1 is expressed in $\mathrm{B}$ and $\mathrm{T}$ cells whereas RasGRP3 is expressed only in B cells. Therefore, our results in humans are in accordance with the experimental data on the expression levels of these proteins in lymphocytes from mice. In addition, in Jurkat T-cell-lines, RasGRP1 maintains expression of TCR $\alpha$ mRNA and surface expression of the TCR/ CD3 complex suggesting a regulatory function of RasGRP1 signal in peripheral $\mathrm{T}$ cells [32]. A subset of SLE patients have defective expression of RasGRP1 because of aberrant splicing. To rule out the hypothesis that the modulation of RasGRP1 transcript level is due to different isoforms of RasGRP1 identified by Yasuda et al. [29], we measured the expression level of the different isoforms present in RNA 


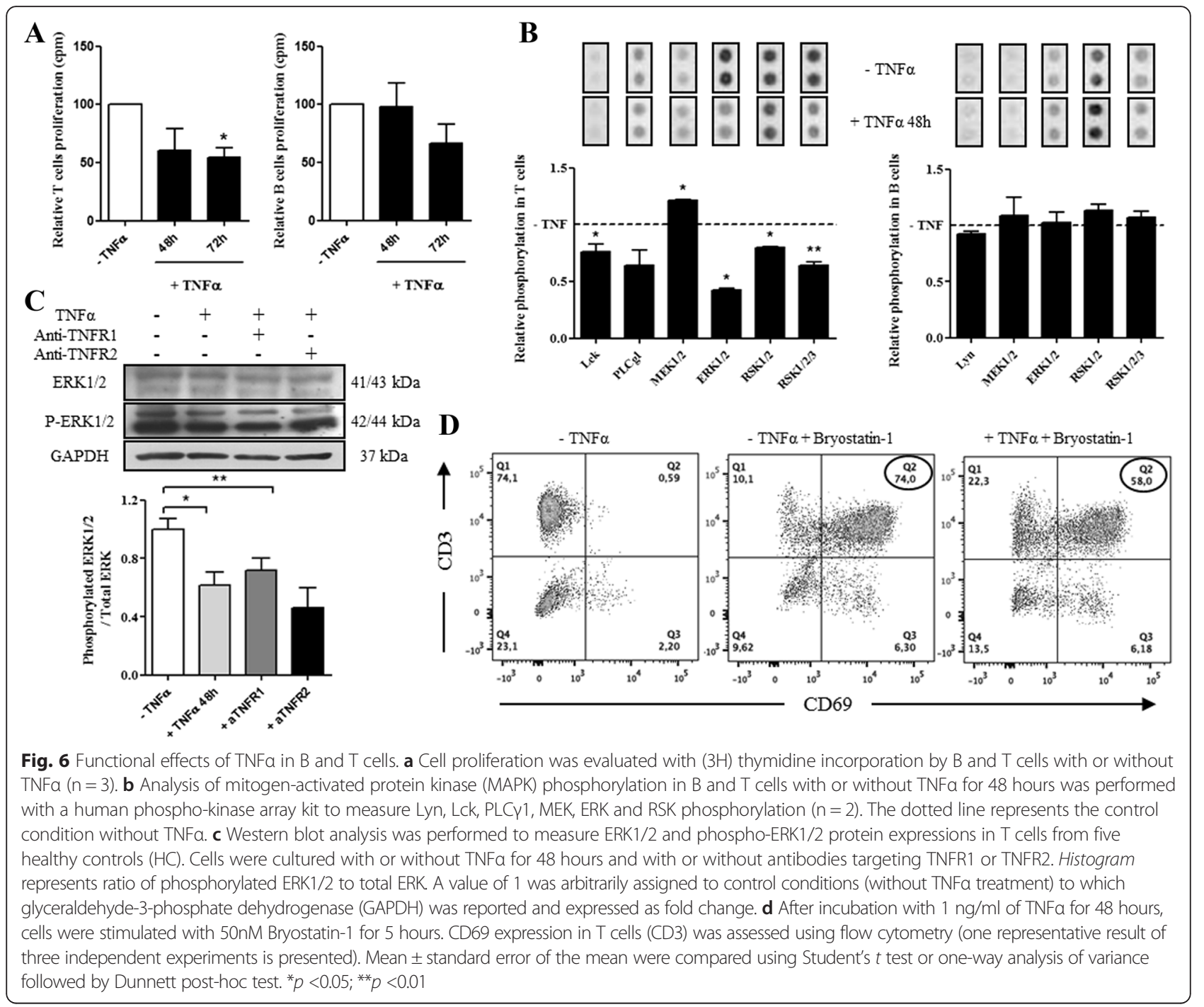

samples from 18 RA patients. We found no substantial difference in the levels of the normal, full-length RasGRP1 transcript in these cells relative to that of the cells from $\mathrm{HC}$ (data not shown). Moreover, the primers chosen for RasGRP1 qRT-PCR were located upstream of exon 11, the exon preferentially deleted in SLE patients and determined by Yasuda et al. [29].

In our study, the analysis of RasGRP1 and RasGRP3 expression levels showed only upregulation of RasGRP1 in $\mathrm{T}$ cells from RA patients compared to $\mathrm{HC}$ (Fig. 2b). Recent genome-wide association studies have identified RasGRP1 as a gene of susceptibility in RA [10], which supports the dysregulation of RasGRP1 in RA. Moreover, RasGRP1 gene expression was also correlated with RA disease activity (Fig. 2d) as was observed in SLE [33]. But RasGRP1 and disease activity were inversely correlated in RA while they were positively correlated in SLE suggesting different ways of regulation in these two diseases. Furthermore, in T cells from RA patients compared with those of
$\mathrm{HC}$, RasGRP1 gene expression level was increased in $\mathrm{T}$ cells (Fig. 2b) while RasGRP1 protein expression was reduced (Fig. 3). However, T cell activation experiments showed that the activation status of these cells sharply increases the RasGRP1 gene expression level (Additional file 5B). So, the increased RasGRP1 gene expression level observed in RA patients could reflect the T cell activation status occurring in this inflammatory context. Moreover, these opposing observations could be explained by the presence of microRNA-21 targeting RasGRP1 mRNA. However, microRNA-21 was previously highlighted as being overexpressed in SLE and RA patients [34, 35].

In vitro studies with $\mathrm{T}$ cells from $\mathrm{HC}$ showed us that TNF $\alpha$ stimulation (a key cytokine in RA pathophysiology) increased RasGRP1 gene expression level (Fig. 4a) while it reduced RasGRP1 protein expression level (Fig. 5a). This discrepancy could be explained by the presence of microRNA-21. Indeed, several studies have demonstrated that microRNA-21 could be upregulated 
by TNF $\alpha$ in cancer or in some inflammatory pathology [36-39]. These data are in agreement with the results found in the RasGRP1 $1^{-/}$mouse model, in which mice became autoimmune-prone and developed a lupus-like phenotype [20]. Indeed, this study demonstrated that RasGRP1 inhibition instigates the emergence of autoimmunity. However, TNF $\alpha$ did not induce modulation of RasGRP1 gene expression level in PBMCs from RA patients (Fig. 1a). The hypothesis would be that the addition of TNFa in vitro to PBMCs from RA patients, already in an inflammatory environment, has no effect on RasGRP1 gene expression level. This phenomenon is even more reinforced by the absence of an effect of TNFo inhibitors on RasGRP1 gene expression level (Fig. 1a). Whereas the use of TNFR1 neutralizing antibody inhibited the TNFo-induced decreasing of RasGRP1 expression level, the use of TNFR2 neutralizing antibody had no effect on TNF $\alpha$ action (Fig. 5a). These results could be explained by the fact that the TNFR1 binds soluble TNF $\alpha$, whereas TNFR2 binds only the membrane TNFa. In accordance with these results, we demonstrated inhibition of $\mathrm{T}$ cell proliferation (Fig. 6a) and also significant inhibition of Lck, ERK and RSK phosphorylation after TNF $\alpha$ treatment (Fig. 6b). We also demonstrated that TNF $\alpha$ inhibited ERK phosphorylation and only the use of TNFR1 neutralizing antibody inhibited this TNF $\alpha$ effect (Fig. 6c). Moreover, bryostatin-1 experiments have confirmed that the TNF $\alpha$ effect observed in T cell proliferation and ERK phosphorylation was indeed due to the decrease of RasGRP1 expression (Fig. 6d).

To better understand RasGRP3 function, we measured RasGRP1 and RasGRP3 gene expression levels in patients treated by adalimumab and etanercept (TNFo inhibitors), and abatacept, a CTLA4-Ig fusion protein as control. RasGRP3 mRNA abundance was decreased only in PBMCs from RA patients treated by TNF $\alpha$ inhibitors but was increased in PBMCs from RA patients treated with abatacept. Furthermore, RasGRP3 gene expression levels were not correlated with DAS28 score (data not shown) and RasGRP3 was not dysregulated in RA patients compared to HC (Figs. 2c and 3b). On the contrary, RasGRP3 gene expression level increased two-fold in PBMCs from RA patients (Fig. 1b) and six-fold in B cells from $\mathrm{HC}$ after 48 hours of culture with TNF $\alpha$ (Figs. 4a and 5b), leading us to conclude that RasGRP3 in B cells was modulated by TNFa. So, it is not surprising to find RasGRP3 as a biomarker of responsiveness to TNF $\alpha$ inhibitors [8]. TNF $\alpha$ induced RasGRP3 increase via TNFR1 and TNFR2. These results are in accordance with the effects of TNF $\alpha$ inhibitors on RasGRP3 gene expression level. Indeed, patients treated by TNF $\alpha$ inhibitors display a decrease of RasGRP3 gene expression level. So, the inhibition of RasGRP3 gene expression seems to be of good prognosis for RA patients. In addition, double mutant mice RasGRP1 ${ }^{-1-} \operatorname{Ras}_{\mathrm{A}} \mathrm{RP} 3^{-1-}$ do not develop signs of autoimmunity contrary to RasGRP1 $1^{-/}$mice [12]. Therefore, RasGRP3 is a biomarker related to TNF $\alpha$ inhibitors.

Aberrant splicing and expression of RasGRP4 were discovered respectively in PBMCs and in the fibroblastlike synoviocytes (FLS) of a subset of RA patients [40, 41]. The defective transcripts led to alteration of the MAPK pathway in PBMCs while the level of RasGRP4 transcript was correlated with the FLS proliferation rate [40, 41]. Any aberrant splicing of RasGRP1 or RasGRP3 was found in our RA patients (data not shown). In experimental arthritis, RasGRP4-null mice did not develop $\mathrm{K} / \mathrm{BxN}$ inflammatory arthritis and intra-articular injection of RasGRP4-specific siRNAs reduced the severity of the disease, suggesting that RasGRP4 is a potential target of therapy in RA [41]. Moreover, RasGRPs represent potential therapeutic targets in cancer [42]. Taken together, the study on RasGRP4 and our study focused on RasGRP1 and RasGRP3 bring new insights into a regulatory function of the RasGRP protein family in FLS and/or in immune cells from RA patients, thereby representing a potential target in RA.

\section{Conclusion}

In summary, our study demonstrated the dysregulation of RasGRP1 in RA patients and the role of RasGRP3 as a biomarker of adalimumab and etanercept. This study suggests a link in T and B cells, never described previously, between RasGRP1 or RasGRP3 and TNF $\alpha$. While the response to TNF $\alpha$ inhibitors in RA patients modulates RasGRP3 gene expression, TNF $\alpha$ inhibits RasGRP1 protein expression, leading to TCR pathway inhibition. We can speculate the establishment of a negative feedback by TNFo to inhibit T cell activation, via RasGRP1 inhibition (Additional file 8). Taken together, the recent study on RasGRP4 and these new data focused on RasGRP1 and RasGRP3 bring new insights into a regulatory function of the RasGRP protein family in FLS and/or in immune cells from RA patients, thereby representing a potential target in RA.

\section{Additional files}

Additional file 1: Table S1. Clinical and biological characteristics of rheumatoid arthritis $(R A)$ patients treated with adalimumab, etanercept or abatacept. (DOC $61 \mathrm{~kb}$ )

Additional file 2: Table S2. Clinical features of patients and healthy controls. (DOC $40 \mathrm{~kb}$ )

Additional file 3: Modulation of RasGRP3 gene expression levels in peripheral blood mononuclear cells (PBMCs) from healthy controls (HC) incubated with TNFa and adalimumab, etanercept, infliximab, certolizumab or golimumab. Quantitative PCR analysis was performed to measure RasGRP3 gene expression levels in PBMCs obtained from HC treated by TNFa and TNFa inhibitors. In each condition, cells were cultured with or without TNFa for 48 hours and adalimumab $(n=4)(\mathbf{a})$, etanercept $(n=3)(\mathbf{b})$, infliximab $(n=3)(\mathbf{c})$, certolizumab $(n=3)(\mathbf{d})$ or 
golimumab $(n=3)$ (e) was added. The relative expression levels (in arbitrary units $(A U)$ ) of RasGRP3 were normalized with 185 RNA abundance. Mean \pm standard error of the mean were compared using one-way analysis of variance followed by Bonferroni post-hoc test: ${ }^{*} p<0.05 ;{ }^{* *} p<0.01$; ${ }^{* * *} p<0.001$. (TIF $1307 \mathrm{~kb}$ )

Additional file 4: $\mathrm{T}$ and $\mathrm{B}$ cell purity. After negative selection of peripheral blood mononuclear cells from healthy controls, buffy coat and rheumatoid arthritis patients, cytometric analysis of T and B cell purity was checked. a Cytometric analysis of human T cell purity with CD3, CD4 and CD8 labeling. $\mathbf{b}$ Cytometric analysis of human B cell purity with CD19 labeling. (TIF $1096 \mathrm{~kb}$ )

Additional file 5: T cell activation induces an increase of RasGRP1 gene expression level. After $T$ cell negative selection, cells were cultured with IL-2 and anti-CD3 antibody for 4 days $(n=3)$. a To evaluate the T cell activation status, HLA-DR and CD25 expressions in T cells (CD3) was checked by flow cytometry. $\mathbf{b}$ quantitative PCR analysis of RasGRPI gene expression was performed. The relative expression levels (in arbitrary units (AU)) of RasGRP1 were normalized with 18S RNA abundance. Mean \pm standard error of the mean were compared using Student's $t$ test: ${ }^{* * *} p<0.001$. (TIF $100 \mathrm{~kb}$ )

\section{Additional file 6: TNF receptor (TNFR)1 and TNFR2 have no effect} on RasGRP1 and RasGRP3 gene expression level in $\mathrm{T}$ and $\mathrm{B}$ cells respectively. Quantitative $P C R$ analysis was performed to measure RasGRP1 and RasGRP3 gene expression levels in $\mathrm{T}$ and $\mathrm{B}$ cells respectively from three healthy controls. T or B cells were exposed to anti-TNFR1 or anti-TNFR2 neutralizing antibodies without TNFa for 48 hours. The relative expression levels (in arbitrary units (AU)) of RasGRP1 and RasGRP3 were normalized with 185 RNA abundance. Mean + standard error of the mean were compared using one-way analysis of variance followed by Bonferroni post-hoc test. (TIF $47 \mathrm{~kb}$ )

Additional file 7: TNFa has no effect on T cell apoptosis. After T cell negative selection, cells were cultured with or without TNFa for 48 and 72 hours. To measure apoptosis, a fluorescein isothiocyanate (FITC) annexin-V Apoptosis Detection Kit (BD Biosciences, USA) was used. After labeling with FITC annexin-V and propidium iodide (PI), cells were analyzed by flow cytometry within 1 hour. a One representative result of three independent experiments is presented. b Histogram represents the mean \pm standard error of the mean (SEM) of percentage of annexin- $V$ positive cells in three independent experiments. Mean \pm SEM were compared using Student's $t$ test. (TIF $1318 \mathrm{~kb}$ )

Additional file 8: A model of RasGRP1 regulation by TNFa. In T cells, TNFa binding to TNF receptor-1 (TNFR1) leads to a decrease of RasGRP1 protein expression after $\mathbf{4 8}$ hours of stimulation. This mechanism prevents mitogen-activated protein kinase activation and induces inhibition of T cell activation and proliferation. We can speculate the establishment of a negative feedback by TNFa to inhibit T cell activation after 48 hours of stimulation, via RasGRP1 inhibition. (TIF $869 \mathrm{~kb})$

\begin{abstract}
Abbreviations
Ab: Antibody; ACR: American College of Rheumatology; ANSM: French National Agency for Medicines; ANOVA: analysis of variance; BCR: B cell receptor; BSA: bovine serum albumin; DAG: DiAcylGlycerol; DAS28: disease activity score 28; ERK: extracellular signal-regulated kinase; FCS: fetal calf serum; FLS: fibroblast-like synoviocyte; GAPDH: glyceraldehyde-3-phosphate dehydrogenase; HC: healthy controls; IL: interleukin; MAPK: mitogen-activated protein kinase; mRNA: messenger ribonucleic acid; NF-KB: nuclear factor-kappa B; PBMC: peripheral blood mononuclear cell; PBS: phosphate-buffered saline; PLC Y1: phospholipase-CY1; qRT-PCR: quantitative real-time polymerase chain reaction; RA: rheumatoid arthritis; RasGRP: ras guanyl nucleotide-releasing protein; RNA: ribonucleic acid; RPMI: Roswell Park Memorial Institute; SDS: sodium dodecyl sulfate; SLE: systemic lupus erythematosus; TCR: T cell receptor; TNFR: tumor necrosis factor receptor; TNFa: tumor necrosis factor a.
\end{abstract}

\section{Competing interests}

The authors disclose no conflicts of interest.

\section{Authors' contributions}

MLG designed and performed experiments, discussed the data and drafted, revised and approved the manuscript. TV initiated the project and was involved in patient recruitment, analyzed the data, and revised and approved the manuscript. CD designed experiments, participated in performing qPCR experiments, discussed the data and revised and approved the manuscript. MF designed and participated in performing western blot experiments, discussed the data, and revised and approved the manuscript. ML participated in performing western blot experiments and in interpretation of data, and revised and approved the manuscript. CG participated in performing cell culture experiments and in analysis and interpretation of data, and revised and approved the manuscript. MH performed GPCR experiments, discussed the data, and revised and approved the manuscript. OB designed experiments, discussed the data and revised and approved the manuscript. XLL initiated the project and was involved in patient recruitment, and revised and approved the manuscript. OV conceived, designed and coordinated the study, discussed the data, and revised and approved the manuscript. TL conceived, designed and coordinated the study, discussed the data and drafted, revised and approved the manuscript.

\section{Authors' information}

Marie-Laure Golinski, PhD, Thibault Vandhuick, MD, Céline Derambure, PhD, Manuel Fréret, PhD, Matthieu Lecuyer, PhD student, Clément Guillou, PhD, Martine Hiron, Bachelor, Olivier Boyer, MD, PhD, Xavier Le Loët, MD, Olivier Vittecoq, MD, PhD, Thierry Lequerré, MD, PhD. This work was supported by grants from the French Society of Rheumatology, UCB (Sirius) and MSD. Marie-Laure Golinski is the recipient of a fellowship from the French ministry of research.

\section{Author details}

${ }^{1}$ INSERM, U905 \& Normandy University, Institute for Research and Innovation in Biomedicine (IRIB), Rouen, France. ${ }^{2}$ Department of Rheumatology \& CIC/ CRB 1404, Rouen University Hospital, Rouen, France. ${ }^{3}$ NeoVasC ERI 28 \& Normandy University, Institute for Research and Innovation in Biomedicine (IRIB), Rouen, France. ${ }^{4}$ Department of Immunology, Rouen University Hospital, Rouen, France. ${ }^{5}$ INSERM U905, Université de Rouen, Faculté de médecine - pharmacie, 22 boulevard Gambetta, 76000 Rouen, France.

Received: 7 September 2015 Accepted: 9 December 2015

Published online: 26 December 2015

\section{References}

1. Hazes JM, Silman AJ. Review of UK data on the rheumatic diseases-2. Rheumatoid arthritis. Br J Rheumatol. 1990;29:310-2.

2. Arend WP, Firestein GS. Pre-rheumatoid arthritis: predisposition and transition to clinical synovitis. Nat Rev Rheumatol. 2012;8:573-86.

3. Boissier MC, Semerano L, Challal S, Saidenberg-Kermanac'h N, Falgarone G. Rheumatoid arthritis: from autoimmunity to synovitis and joint destruction. J Autoimmun. 2012;39:222-8.

4. McInnes IB, Schett G. Cytokines in the pathogenesis of rheumatoid arthritis. Nat Rev Immunol. 2007;7:429-42

5. Brennan FM, McInnes IB. Evidence that cytokines play a role in rheumatoid arthritis. J Clin Invest. 2008;1 18:3537-45.

6. Keffer J, Probert L, Cazlaris H, Georgopoulos S, Kaslaris E, Kioussis D, et al. Transgenic mice expressing human tumour necrosis factor: a predictive genetic model of arthritis. EMBO J. 1991;10:4025-31.

7. Singh JA, Christensen R, Wells GA, Suarez-Almazor ME, Buchbinder R, Lopez-Olivo MA, et al. Biologics for rheumatoid arthritis: an overview of Cochrane reviews. Sao Paulo Med J. 2010:128:309-10.

8. Lequerré T, Gauthier-Jauneau AC, Bansard C, Derambure C, Hiron M, Vittecoq $\mathrm{O}$, et al. Gene profiling in white blood cells predicts infliximab responsiveness in rheumatoid arthritis. Arthritis Res Ther. 2006;8:R105.

9. Lequerré T, Bansard C, Vittecog O, Derambure C, Hiron M, Daveau M, et al. Early and long-standing rheumatoid arthritis: distinct molecular signatures identified by gene-expression profiling in synovia. Arthritis Res Ther. 2009;11:R99.

10. Eyre S, Bowes J, Diogo D, Lee A, Barton A, Martin P, et al. High-density genetic mapping identifies new susceptibility loci for rheumatoid arthritis. Nat Genet. 2012;44:1336-40.

11. Ebinu JO, Bottorff DA, Chan EY, Stang SL, Dunn RJ, Stone JC. RasGRP, a Ras guanyl nucleotide-releasing protein with calcium- and diacylglycerol-binding motifs. Science. 1998;280:1082-6. 
12. Coughlin JJ, Stang SL, Dower NA, Stone JC. RasGRP1 and RasGRP3 regulate B cell proliferation by facilitating B cell receptor-Ras signaling. J Immunol. 2005;175:7179-84.

13. Stone JC. Regulation of Ras in lymphocytes: get a GRP. Biochem Soc Trans. 2006;34:858-61.

14. Zheng Y, Liu H, Coughlin J, Zheng J, Li L, Stone JC. Phosphorylation of RasGRP3 on threonine 133 provides a mechanistic link between PKC and Ras signaling systems in B cells. Blood. 2005;105:3648-54.

15. Aiba Y, Oh-hora M, Kiyonaka S, Kimura Y, Hijikata A, Mori Y, et al. Activation of RasGRP3 by phosphorylation of Thr-133 is required for $B$ cell receptor-mediated Ras activation. Proc Natl Acad Sci USA. 2004;101:16612-7.

16. Teixeira C, Stang SL, Zheng Y, Beswick NS, Stone JC. Integration of DAG signaling systems mediated by PKC-dependent phosphorylation of RasGRP3. Blood. 2003:102:1414-20.

17. Liu SK, Berry DM, McGlade CJ. The role of Gads in hematopoietic cell signalling. Oncogene. 2001;20:6284-90.

18. Dal Porto JM, Gauld SB, Merrell KT, Mills D, Pugh-Bernard AE, Cambier J. B cell antigen receptor signaling 101. Mol Immunol. 2004;41:599-613.

19. Guilbault B, Kay RJ. RasGRP1 sensitizes an immature B cell line to antigen receptor-induced apoptosis. J Biol Chem. 2004:279:19523-30.

20. Coughlin JJ, Stang SL, Dower NA, Stone JC. The role of RasGRPs in regulation of lymphocyte proliferation. Immunol Lett. 2006;105:77-82.

21. Stone JC. Regulation and Function of the RasGRP Family of Ras Activators in Blood Cells. Genes Cancer. 2011:2:320-34.

22. Bivona TG, Perez De Castro I, Ahearn IM, Grana TM, Chiu VK, Lockyer PJ, et al. Phospholipase Cgamma activates Ras on the Golgi apparatus by means of RasGRP1. Nature. 2003;424:694-8.

23. Dower NA, Stang SL, Bottorff DA, Ebinu JO, Dickie P, Ostergaard HL, et al. RasGRP is essential for mouse thymocyte differentiation and TCR signaling. Nat Immunol. 2000;1:317-21.

24. Arnett FC, Edworthy SM, Bloch DA, McShane DJ, Fries JF, Cooper NS, et al. revised criteria for the classification of rheumatoid arthritis. Arthritis Rheum. 1987:1988(31):315-24.

25. Aletaha D, Neogi T, Silman AJ, Funovits J, Felson DT, Bingham CO, et al. 2010 Rheumatoid arthritis classification criteria: an American College of Rheumatology/European League Against Rheumatism collaborative initiative. Arthritis Rheum. 2010;62:2569-81.

26. D'Agostino MA, Wakefield R, Berner Hammer H, Vittecoq O, Galeazzi M, Balint P. Assessment of omeract global power doppler ultrasonography 44-joint scoring system and reduced joint scoring systems in rheumatoid arthritis patients treated with abatacept plus background methotrexate [abstract]. Arthritis Rheum. 2012;64(Suppl):352.

27. Poltorak M, Meinert I, Stone JC, Schraven B, Simeoni L. Sos1 regulates sustained TCR-mediated Erk activation. Eur J Immunol. 2014;44:1535-40.

28. Roose JP, Mollenauer M, Ho M, Kurosaki T, Weiss A. Unusual interplay of two types of Ras activators, RasGRP and SOS, establishes sensitive and robust Ras activation in lymphocytes. Mol Cell Biol. 2007:27:2732-45.

29. Yasuda S, Stevens RL, Terada T, Takeda M, Hashimoto T, Fukae J, et al. Defective expression of Ras guanyl nucleotide-releasing protein 1 in a subset of patients with systemic lupus erythematosus. J Immunol. 2007:179:4890-900.

30. Ksionda O, Limnander A, Roose JP. RasGRP Ras guanine nucleotide exchange factors in cancer. Front Biol. 2013;8:508-32.

31. Ebinu JO, Stang SL, Teixeira C, Bottorff DA, Hooton J, Blumberg PM, et al. RasGRP links T-cell receptor signaling to Ras. Blood. 2000:95:3199-203.

32. Markegard E, Trager E, Yang CW, Zhang W, Weiss A, Roose JP. Basal LAT-diacylglycerol-RasGRP1 signals in T cells maintain TCRa gene expression. PLoS One. 2011;6:25540.

33. Rapoport MJ, Bloch O, Amit-Vasina M, Yona E, Molad Y. Constitutive abnormal expression of RasGRP-1 isoforms and low expression of PARP-1 in patients with systemic lupus erythematosus. Lupus. 2011:20:1501-9.

34. Pan W, Zhu S, Yuan M, Cui H, Wang L, Luo X, et al. MicroRNA-21 and microRNA-148a contribute to DNA hypomethylation in lupus CD4+ T cells by directly and indirectly targeting DNA methyltransferase 1. J Immunol. 2010;184:6773-81.

35. Wang $H$, Peng W, Ouyang $X$, Li W, Dai Y. Circulating microRNAs as candidate biomarkers in patients with systemic lupus erythematosus. Transl Res. 2012;160:198-206.
36. Cottonham $\mathrm{CL}$, Kaneko S, Xu L. miR-21 and miR-31 converge on TIAM1 to regulate migration and invasion of colon carcinoma cells. J Biol Chem. 2010;285:35293-302.

37. Guinea-Viniegra J, Jiménez $M$, Schonthaler HB, Navarro R, Delgado $Y$, Concha-Garzón MJ, et al. Targeting miR-21 to treat psoriasis. Sci Transl Med. 2014;6:225-31.

38. Kagiya T, Nakamura S. Expression profiling of microRNAs in RAW264.7 cells treated with a combination of tumor necrosis factor alpha and RANKL during osteoclast differentiation. J Periodontal Res. 2013;48:373-85.

39. Zarjou A, Yang S, Abraham E, Agarwal A, Liu G. Identification of a microRNA signature in renal fibrosis: role of miR-21. Am J Physiol Renal Physiol. 2011;301:793-801

40. Hashimoto $\mathrm{T}$, Yasuda $\mathrm{S}$, Koide $\mathrm{H}$, Kataoka H, Horita T, Atsumi T, et al. Aberrant splicing of the hRasGRP4 transcript and decreased levels of this signaling protein in the peripheral blood mononuclear cells in a subset of patients with rheumatoid arthritis. Arthritis Res Ther. 2011;13:R154.

41. Kono M, Yasuda S, Stevens RL, Koide H, Kurita T, Shimizu Y, et al. Ras guanine nucleotide-releasing protein 4 is aberrantly expressed in the fibroblast-like synoviocytes of patients with rheumatoid arthritis and controls their proliferation. Arthritis Rheumatol. 2015;67:396-407.

42. Song X, Lopez-Campistrous A, Sun L, Dower NA, Kedei N, Yang J, et al. RasGRPs are targets of the anti-cancer agent ingenol-3-angelate. PLoS One. 2013;8:72331.

\section{Submit your next manuscript to BioMed Central and we will help you at every step:}

- We accept pre-submission inquiries

- Our selector tool helps you to find the most relevant journal

- We provide round the clock customer support

- Convenient online submission

- Thorough peer review

- Inclusion in PubMed and all major indexing services

- Maximum visibility for your research

Submit your manuscript at www.biomedcentral.com/submit
) Biomed Central 